\title{
Work related muskuloskeletal disorders among dentists at the university dental clinic in Skopje
}

\author{
Vasilka Rendžova, Sonja Apostolska, Marina Eftimoska, Biljana Džipunova, Vesna Filipovska \\ Ss. Cyril and Methodius University, Faculty of Dental Medicine, Skopje, R Macedonia
}

\begin{abstract}
SUMMARY
Introduction Musculoskeletal disorders (MSDs) are one of the most common types of work-related diseases that affect health workers, especially dentists. The aim of our study was to examine the presence of musculoskeletal disorders among dentists at the university dental clinic in correlation with risk factors.

Materials and methods A questionnaire survey was carried out among 78 dental practitioners aged between 20 to 60 years old, employed at the university dental clinic. Questions included data on physical and psychosocial workload, perceived general health and occurrence of musculoskeletal complaints in the past 12 months, chronic complaints, frequency and length of breaks, exercising habits as well as medical care seeking.

Results Pain in the back, neck and shoulders (84.6\% / 85.9\%) was the most common complaint among the majority of respondents, while reduced range of movement was noticed among significantly fewer subjects, mostly between 40-60 years of age. Prolonged statistic position was considered to be one of the main causes of MSDs (82.05\%) while $73.08 \%$ of respondents stated at least two more reasons beside this one.

Conclusion The percentage of MSDs prevalence among dentists in public health sector is high. More extensive surveys should be undertaken to cover larger group of dentists from both private and public sector, in order to obtain complete analysis of the prevalence of occupational disorders in our country.
\end{abstract}

Keywords: dentists; ergonomics; musculoskeletal disorders

\section{INTRODUCTION}

According to the US department of Safety and Health Administration musculoskeletal disorders (MSDs) develop as a result of imbalance between the level of demand of physical effort at the workplace and physical capacity of worker [1]. Despite having physical and psychological effects, professional disorders can impact worker's economic state and wellbeing on a larger scale, which contributes to more frequent absence from work and early retirement [2]. Some of professional hazards in dentistry are exposure to chemical substances, radiation, dangerous biological materials and inadequate body positioning during work. Based on data received from the Occupational Information Network and US Department of Labour database, dentistry was ranked as profession that has the worst impact on the health of workers [3].

Musculoskeletal disorders are one of the most common types of work-related diseases that affect health workers, especially dentists. There are multiple factors that contribute to development of musculoskeletal disorders among dentists [4]: continuous movements, insufficient lighting, improper body position during work, psychological stress, genetics, physical conditions, age and weight $[5,6]$.

Ergonomics is a science about design of products and regulations that assure maximal utility and safety during work. It also studies relationship between workers, equipment and work environment. The implementation of ergonomic conditions and principles in the work place is important element in the prevention of musculoskeletal disorders and improvement of productivity and effectiveness of dentist for a longer period of time [7].

The aim of our study was to examine the presence of musculoskeletal disorders among dentists at the university dental clinic in Skopje in correlation with work- related risk factors.

\section{MATERIAL AND METHOD}

This study examined 78 dental practitioners aged between 20 to 60 years old, employed at the public health institution Dental Clinic Centre. They were given a Standard Nordisk Questionnaire consisting of two parts [8]. The first part consisted of questions regarding the gender and age, years of working experience, average working hours per day and per week, number and length of their breaks and position of their bodies while working.

The second part (Standard Nordisk Questionnaire) consisted of questions addressing the musculoskeletal disorders, the presence of genetic predisposition, the frequency of painkiller usage and questions regarding diagnosis and request for medical help among patients with these disorders.

In addition to the Standard Nordisk questionnaire, another questionnaire was distributed. This questionnaire 
addressed frequency and length of breaks, position of body during work, exercising habits, wearing orthopedic shoes and utilization of alternative methods for improving health. The obtained results were analyzed with descriptive statistical analysis.

\section{RESULTS}

The research was conducted on $79.59 \%$ (79/98) of the total number of dental employees at the University dental clinic, Skopje. Employees that did not participate in the research were absent due to illness, lack of time or other subjective reasons. The sample consisted of specialists $87.18 \%$ (oral surgeons, prosthodontists, orthodontists, pedodontists, periodontologists and endodontologists) and $12.82 \%$ general dentists. Most of the participants held a postgraduate degree $(\mathrm{MSc}, \mathrm{PhD})$.

Gender distribution among the participants was not equal. $73.08 \%$ of respondents were female at age 20-60, with an average working experienceof 16.9 years. The average working experience of male participants was 17.24 years. Furthermore, the amount of effective working hours among $82.05 \%$ of the respondents was 30 hours per week, while $17.95 \%$, out of which were mainly male respondents, worked effectively for 40 hours per week.

Table 1 shows work related reasons that caused musculoskeletal disorders or discomfort. $57.69 \%$ of respondents showed genetic predisposition. $82.05 \%$ of respondents spent significant amount of time in the same position while working, $52.56 \%$ respondents reported that their work required investing lot of strength, $62.82 \%$ reported their work required repetition of movements. Furthermore, $66.67 \%$ of the respondents reported exposure to constant machine vibrations as a part of their every day work, while $73.08 \%$ described two or three work-related conditions at the same time.

Another part of our research focused on pain and other complaints related to the musculoskeletal system (Table 2 ), where 66 respondents $(84.61 \%)$ reported pain in the lower back, out of which $33.33 \%$ reported back pain in the last 12 months. Upper back pain was noticed among $60.26 \%$ of respondents, of which $19.23 \%$ have been experiencing pain in the last 12 months. $14.10 \%$ of respondents had reduced movements, all of the age group of 40-60 years with an average length of working experience, 22.5 years. None of the respondents from the age group of 20-40 years reported presence of upper back pain. The majority of respondents (85.9\%) of both age groups reported the presence of shoulder and neck pain. Moreover, 28 (35.9\%) examinees reported pain in hand fingers, while $14 \%$ of examinees experienced reduced hand strength, while holding instruments. All subjects had multiple musculoskeletal conditions. $47.44 \%$ of respondents used painkillers often and $33.33 \%$ of respondents used painkillers on occasional basis. However, despite the high prevalence of complaints among respondents related to pain in different parts of the MS system, only $37.18 \%$ sought professional help and have been diagnosed with MSD.
The results further showed that $51.28 \%$ of respondents were familiar with ergonomic principles of work, while $43.59 \%$ were more informed. Partial application of ergonomic principles was noticed among $55.13 \%$ of respondents and only 14 respondents (17.95\%) fully applied them during work. Another finding was that most of respondents (67.97\%) worked in both positions, seating

Table 1. Work related reasons that cause musculoskeletal disorders or discomfort

Tabela 1. Razlozi vezani za rad, koji uzrokuju poremećaje muskuloskeletnih organa ili nelagodnost

\begin{tabular}{|l|c|}
\hline $\begin{array}{l}\text { Variables } \\
\text { Promenljive }\end{array}$ & $\begin{array}{c}\text { Number (\%) } \\
\text { Broj (\%) }\end{array}$ \\
\hline $\begin{array}{l}\text { Total number of respondents } \\
\text { Ukupan broj ispitanika }\end{array}$ & 78 \\
\hline $\begin{array}{l}\text { Average age } \\
\text { Prosečna starost }\end{array}$ & $41.56 \pm 2.1$ \\
\hline $\begin{array}{l}\text { Men } \\
\text { Muškarci }\end{array}$ & $26.92 \%$ \\
\hline $\begin{array}{l}\text { Women } \\
\text { Žene }\end{array}$ & $73.8 \%$ \\
\hline $\begin{array}{l}\text { Average working experience - men } \\
\text { Prosečno radno iskustvo - muškarci }\end{array}$ & 17.24 years \\
\hline $\begin{array}{l}\text { Average working experience - women } \\
\text { Prosečno radno iskustvo - žene }\end{array}$ & 16.9 years \\
\hline $\begin{array}{l}\text { Effective working hours } \geq 30 \text { hours per week } \\
\text { Efektivno radno vreme } \geq 30 \text { sati nedeljno }\end{array}$ & $64(82.05 \%)$ \\
\hline $\begin{array}{l}\text { Effective working hours } \geq 40 \text { hours per week } \\
\text { Efektivno radno vreme } \geq 40 \text { sati nedeljno }\end{array}$ & $14(17.95 \%)$ \\
\hline $\begin{array}{l}\text { Genetic predisposition } \\
\text { Genetska predispozicija }\end{array}$ & $45(57.69 \%)$ \\
\hline $\begin{array}{l}\text { Specialists } \\
\text { Specijalisti }\end{array}$ & $68(87.18 \%)$ \\
\hline $\begin{array}{l}\text { Continuous body positioning } \\
\text { Dugotrajan isti položaj tela }\end{array}$ & $64(82.05 \%)$ \\
\hline $\begin{array}{l}\text { Repeated movements } \\
\text { Ponovljeni pokreti }\end{array}$ & $52(66.67 \%)$ \\
\hline $\begin{array}{l}\text { Vibrations from machines and instruments } \\
\text { Vibracije od mašina i instrumenata }\end{array}$ & $41(52.56 \%)$ \\
\hline $\begin{array}{l}\text { Usage of force } \\
\text { Upotreba sile } \\
\text { Dve ili više karakteristika }\end{array}$ & $67 \%)$ \\
\hline
\end{tabular}

Table 2. Prevalence of musculoskeletal complaints among dentists Tabela 2. Prevalenca mišićno-skeletnih tegoba kod stomatologa

\begin{tabular}{|l|c|}
\hline $\begin{array}{l}\text { Variables } \\
\text { Promenljive }\end{array}$ & $\begin{array}{c}\text { Number (\%) } \\
\text { Broj (\%) }\end{array}$ \\
\hline $\begin{array}{l}\text { Pain in the lower back } \\
\text { Bol u donjem delu leđa }\end{array}$ & $66(84.61 \%)$ \\
\hline $\begin{array}{l}\text { Experiencing pain in the last } 12 \text { months } \\
\text { Bol u donjem delu leđa u poslednjih } 12 \text { meseci }\end{array}$ & $26(33.33 \%)$ \\
\hline $\begin{array}{l}\text { Pain in the upper back } \\
\text { Bol u gornjem delu leđa }\end{array}$ & $47(60.26 \%)$ \\
\hline $\begin{array}{l}\text { Experiencing pain in the last } 12 \text { months } \\
\text { Bol u gornjem delu leđa u poslednjih 12 meseci }\end{array}$ & $15(19.23 \%)$ \\
\hline $\begin{array}{l}\text { Reduced ability to move } \\
\text { Smanjena sposobnost kretanja }\end{array}$ & $11(14.10 \%)$ \\
\hline $\begin{array}{l}\text { Pain in the neck and shoulders } \\
\text { Bol u vratu i ramenima }\end{array}$ & $67(85.9 \%)$ \\
\hline $\begin{array}{l}\text { Pain in the hand and fingers } \\
\text { Bol u ruci i prstima }\end{array}$ & $28(35.9 \%)$ \\
\hline $\begin{array}{l}\text { Have been diagnosed with MSDs and sought medical help } \\
\text { Dijagnostikovano je MSDs i tražilo medicinsku pomoć }\end{array}$ & $37.18 \%$ \\
\hline $\begin{array}{l}\text { Have been taking proper medications/ painkillers } \\
\text { Uzimali lekove protiv bolova }\end{array}$ & $37(47.44 \%)$ \\
\hline
\end{tabular}


Table 3. Application of ergonomic principles and exercise Tabela 3. Primena ergonomskih principa i vežbanja

\begin{tabular}{|l|c|}
\hline $\begin{array}{l}\text { Variables } \\
\text { Promenljive }\end{array}$ & $\begin{array}{l}\text { Number (\%) } \\
\text { Broj (\%) }\end{array}$ \\
\hline $\begin{array}{l}\text { Familiar with the ergonomic principles of work } \\
\text { Upoznati sa ergonomskim principima rada }\end{array}$ & $40(51.28 \%)$ \\
\hline $\begin{array}{l}\text { Partial knowledge regarding ergonomic principles of work } \\
\text { Delimično upoznati sa ergonomskim principima rada }\end{array}$ & $34(43.59 \%)$ \\
\hline $\begin{array}{l}\text { Partial application of the ergonomic principles of work } \\
\text { Delimična primena ergonomskih principa rada }\end{array}$ & $43(55.13 \%)$ \\
\hline $\begin{array}{l}\text { Full application of the ergonomic principles of work } \\
\text { Potpuna primena ergonomskih principa rada }\end{array}$ & $14(17.95 \%)$ \\
\hline $\begin{array}{l}\text { Combined work (sitting and standing) } \\
\text { Kombinovani rad (sedenje i stajanje) }\end{array}$ & $53(67.97 \%)$ \\
\hline $\begin{array}{l}\text { Working while sitting } \\
\text { Rad u sedećem položaju }\end{array}$ & $5(6.41 \%)$ \\
\hline $\begin{array}{l}\text { Physical therapy (occasional) } \\
\text { Fizikalna terapija (povremena) }\end{array}$ & $40(51.28 \%)$ \\
\hline $\begin{array}{l}\text { Massage (occasional) } \\
\text { Masaža (povremena) }\end{array}$ & $32(41.03 \%)$ \\
\hline $\begin{array}{l}\text { Exercising (frequent) } \\
\text { Vežbanje (često) }\end{array}$ & $26(33.33 \%)$ \\
\hline $\begin{array}{l}\text { Exercising (occasional) } \\
\text { Vežbanje (povremeno) }\end{array}$ & $38 \%)$ \\
\hline
\end{tabular}

and standing and only $6.41 \%$ of the respondents (mostly from the group of 20-40 years) were working in seating position (Table 3).

Almost all respondents were familiar that exercise, massage, physical therapy and other alternative methods affect musculoskeletal system and reduce the occurrence of musculoskeletal disorders, but only $40(51.28 \%)$ occasionally went to physical therapy and $41.03 \%$ occasionally got massages. Only 26 (33.33\%) respondents exercised frequently while $48 \%$ exercised occasionally even though exercise (strength and muscle stretching) is one of the most important factors for the preservation of the musculoskeletal system health (Table 3).

\section{DISCUSSION}

The term MSDs refers to injuries that affect soft tissues such as muscles, tendons, ligaments, joints, cartilage and nervous system. These conditions most often affect arms and back and are known as cumulative disorders caused by trauma, repetitive movements, stress, or as a syndrome of occupational overload. MSDs develop gradually within weeks, months and years and in a longer period of time may cause disabilities [9].

Several studies have examined the relationship between the occurrence of MSDs and type of profession. Dentists belong to vulnerable group constantly exposed to the threat of occupational disorders due to their static activity while working continuously for a longer period of time. Other factors that contribute to the presence of MSDs are lack of small breaks, constant repetitive movements of the arms and wrists and use of force while working $[10,11]$. Another important factor that influences the occurrence of musculoskeletal disorders is working environment. According to Custodio, the positions recommended by ISO and FDI, for patient and dentist (for example, the patient is in laying position and at the "9 o'clock" orientation to the dentist) are rarely observed due to the limited workspace [12]. In their study, Burke, Main and Freeman have come to the conclusion that approximately one third of dentists are forced to retire early because of work-related difficulties [13]. A number of dental studies reported that on average, two out of three dentists experienced musculoskeletal pain [14,15]. Most commonly reported disorders of this kind occur around spinal area, shoulders and wrist that can result in lower back pain, neck pain, brachial pain, shoulder tendonitis, carpal tunnel syndrome etc. [16, 17, 18].

Sartorio et al. indicated higher presence of MSDs (5493\%) among dental staff in Italy and significantly higher risk of exposure among senior and female dentists [19]. This study further showed that backbone, shoulder, elbow and arm were most affected.

Our research was conducted in order to investigate the prevalence of musculoskeletal disorders among dentists in the largest public health institution in our country. Seventy-eight dentists aged 20 to 60 years participated in the study. Both female and male participants were involved, specializing in different dental areas and most of them held a postgraduate degree (Master's or Doctoral Degree).

The pain in the back, neck and shoulders was the most common complaint among the majority of respondents, while reduced range of movement was noticed among significantly fewer subjects, mostly between $40-60$ years of age. An interesting finding was that all examinees experienced more than one musculoskeletal disorder. Furthermore, hand pain was present with significantly lower percentage compared to the pain in the back, neck and shoulders that was connected and dependent on the area of specialty. Our examination included respondents from different dental areas of specialty that share similar positioning of neck, shoulders and spine while working. The application of force at work and vibrations is related to only few dental areas that require use of hands and fingers and that explains low percentage of complaints related to hand and finger disorders.

The results of our research agree with the results presented by several authors. Legg and Smith surveyed 285 Australian dentists, out of which $90 \%$ practiced general dentistry, and most of complaints were related to neck, shoulder, and back. About $37.5 \%$ of dentists needed medical care, while $25 \%$ reached the point of disability and 9\% required prolonged absence from their practice [20]. Alexopoulos EC et al. concluded that hand/wrist complaints $(46 \%$ / 60\%) were one of the most important occupation related musculoskeletal disorder and ergonomic and educational interventions could hold a prominent role in its prevention [21]. Several authors pointed out that position of dental chair needed to be adjusted according to the height of the dentist, together with the light source, in order to prevent the occurrence of MSDs [22]. Furthermore, the results show high percentage of lower back pain that can be related to working conditions as large number of respondents had long work experience or inability to apply ergonomic principles of work (defective workplace, poor lighting, inability to work in a seating position, etc.). 
Prolonged statistic position is considered to be one of the main causes of MSDs and should be addressed properly in order for dentists to practice preventive measures $[23,24]$. These findings correspond with data obtained from our survey where $82.05 \%$ of respondents reported prolonged static posture as a cause for disorders and $73.08 \%$ of respondents reported at least two more reasons beside this one.

Recently, several studies have highlighted other factors such as obesity and physical inactivity in the development of chronic MSDs among dentists. Moreover, due to exhaustion and fatigue, caused by heavy workload and long working hours, dentists avoid physical exercise and activities $[25,26]$. Published literature points out the important role of physical activity (pilates, aerobics) as a preventative ergonomic measure. Aerobic exercise improves the flow of oxygen in tissues, thereby increasing efficiency. Stretching exercises are effective measure for relaxing and reducing muscle tension caused by improper posture [27]. It is well known that prolonged static posture requires contraction of $50 \%$ of body's muscles explain the need for stretching.

Even though all respondents from our research were aware that regular exercise is of exceptional importance to the musculoskeletal health, only one third of respondents exercised regularly, while $48 \%$ exercised only occasionally. The percentage of respondents who were utilizing alternative methods such as massage or spa centers was even lower. Besides the high percentage of musculoskeletal complaints among respondents, only $37.18 \%$ sought professional help and only $47 \%$ took medication to reduce pain, which comes as a result either from the respondent's negligence or the frivolous approach to this issue.

This study covered only dentists employed in the public sector. Further studies are advised to examine dentists from private dental institutions, where working conditions impose more complex schedule of work, fewer breaks and free time as well as fewer absences from work.

\section{CONCLUSION}

The percentage of MSDs prevalence among dentists in public health sector is high. More extensive surveys should be undertaken to cover larger group of dentists from both private and public sector, in order to get complete analysis of the prevalence of occupational disorders in our country. Consequently, appropriate measures should be taken in order to inform and educate dentists regarding MSD. Awareness should be raised pointing out that dentistry, as a profession, is susceptible to high risk of occupational disorders and injuries. Ignorance and avoidance of the MSDs symptoms could lead to early career ending and therefore it is important to have a knowledge regarding its prevention.

\section{REFERENCES}

1. Gupta A, Ankola AV, Hebbal M. Dental Ergonomics to Combat Musculoskeletal Disorders: A Review. Int J Occup Saf Ergon. 2013; 19(4):561-71. [DOI: 10.1080/10803548.2013.11077005]
2. Fulton-Kehoe D, Franklin G, Weaver M, Cheadle A. Years of productivity lost among injured workers in Washington State: Modeling disability burden in workers' compensation. Am J Ind Med. 2000; 37:656-62. [PMID: 10797509]

3. Natalie R. La Rochelle. Virginia Commonwealth University. WorkRelated Musculoskeletal Disorders Among Dentists and Orthodontists. http://scholarscompass.vcu.edu/etd

4. Stewart WF, Ricci JA, Chee E, Morganstein D, Lipton R. Lost productive time and cost due to common pain conditions in the US workforce. JAMA. 2003; 290:2443-54.

[DOI: 10.1001/jama.290.18.2443] [PMID: 14612481]

5. Smith DR, Wei N, Zhang YJ, Wang RS. Musculoskeletal complaints and psychosocial risk factors among physicians in mainland China. Int J Ind Ergon. 2006; 36:599-603.

[DOl: 10.1093/occmed/kqh117]

6. De Sio S, Traversini V, Rinaldo F, Colasanti V, Buomprisco G, Perri R, et al. Ergonomic risk and preventive measures of musculoskeletal disorders in the dentistry environment: an umbrella review. Peer). 2018; 15(6):e4154. [DOI: 10.7717/peerj.4154] [PMID: 29362689]

7. Sarkar PA, Shigli AL. Ergonomics in General Dental Practice. People's Journal of Scientific Research. 2012; 5(1):56-60.

8. Kuorinka I, Jonsson B, Kilborn A et al. Standardised Nordic questionnaires for the analysis of musculoskeletal symptoms. Applied Ergonomics. 1987; 18(3):233-7. [PMID: 15676628]

9. Ergonomics: The Study of Work U.S. Department of Labour Occupational Safety and Health Administration. 2000 Available from: https://www.osha.gov/Publications/osha3125.pdf.

10. Szeto GP, Ho P, Ting AC, Poon JT, Cheng SW, Tsang RC. Work-related musculoskeletal symptoms in surgeons. J Occup Rehabil. 2009; 19:175-84. [DOI: 10.1007/s10926-009-9176-1] [ PMID:19381790]

11. Stomberg MW, Tronstad SE, Hedberg K et al. Work-related musculoskeletal disorders when performing laparoscopic surgery. Surg Laparosc Endosc Percutan Tech. 2010; 20:49-53.

[DOI: 10.1097/SLE.0b013e3181cded54] [PMID: 20173622]

12. Custodio RA, Silva CE, Brandão JG. 2012. Ergonomics work analysis applied to dentistry, a Brazilian case study. Work 41 (Suppl 1): 690-7. [DOI: 10.3233/WOR-2012-0227-690] [PMID:22316802]

13. Burke FJ, Main JR, Freeman R. The practiceof dentistry: an assessment of reasons for premature retirement. Br Dent J. 1997; 182(7):250-4. [PMID: 9134812]

14. Rucker LM. Technology meets ergonomicsin the dental clinic: new toys for old games? J Am Coll Dent. 2000; 67(2):26-9. [PMID: 10941230]

15. Bedi HS, Moon NJ, Bhatia V, Sidhu GK, Khan N. Evaluation of Musculoskeletal Disorders in Dentists and Application of DMAIC Technique to Improve the Ergonomics at Dental Clinics and MetaAnalysis of Literature. J Clin Diagn Res. 2015; 9(6):ZC01-3. [DOI: 10.7860/JCDR/2015/14041.6126] [PMID: 26266205]

16. Morse T, Bruneau H, Dussetschleger J. Musculoskeletal disorders of the neck and shoulder in the dental professions. Work. 2010; 35(4):419-29. [DOI: 10.3233/WOR-2010-0979] [PMID: 20448321]

17. Tirgar A, Javanshir K, Talebian A, Amini F, Parhiz A. Musculoskeletal disorders among a group of Iranian general dental practitioners. J Back Musculoscelet Rehab 2015; 28(4):755-9. [DOI: 10.3233/BMR-140579] [PMID: 25547232]

18. Biswas R, Sachdev V, Jindal V, Ralhab S. Musculoskeletal disorders and ergonomic risk factors in dental practice. Ind J Dent Sci. 2012; 4(1):70-4.

19. Sartorio F, Vercelli S, Ferriero G, D'Angelo F, Migliario M, Franchignoni M. Work-related musculoskeletal diseases in dental professionals. Prevalence and risk factors. G Ital Med Lav Ergon. 2005; 27(2):165-9. [PMID: 16124525]

20. Leggat PA, Smith DR. Musculo skeletal disorders self reported by dentists in Queensland, Australia. Aust Dent J. 2006; 51(4):324-7. [PMID: 17256307]

21. Alexopoulos EC, Stathi IC, Charizani F. Prevalence of musculoskeletal disorders in dentists. BMC Musculoskelet Disord. 2004; 5:16. [DOI: 10.1186/1471-2474-5-16] [PMID: 15189564]

22. Gosavi SS, Gosavi SY, Jawade RS. Posturedontics: reducing the stress in dentistry. World J Dent. 2012; 3(4):335-9.

[DOI: 10.5005/jp-journals-10015-1185] 
23. Peros K, Vodanovic M, Mestrovic S, Rosin-Grget K, Valic M. Physical fitness course in the dental curriculum and prevention of low back pain. J Dent Educat. 2011; 75(6):761-7. [PMID: 21642521]

24. Roberts S, Gallardo F, Brown R. Cat of month. Critically appraised topics. Dentists's awareness of posture in reducing pain in musculoskeletal disorders. Tex Dent J. 2014; 131(4):296.

25. Harutunian K, Gargallo-Albiol J, Figueiredo R, Gay-Escoda C. Ergonomics and Musculo skeletal pain among postgraduate students and faculty members of the school of dentistry of the university of Barcellona (Spain). A cross sectional study. Med Oral Patol Oral Cir Bucal. 2011; 16(3):e425-9. [PMID: 20711125]
26. Thakar S, Shivlingesh K, Jayaprakash K, Gupta B, Gupta N, Anand $R$, et al. High levels of physical inactivity amongst dental professionals: a questionnaire based cross sectional study. J Clin Diagn Res. 9(1):ZC43-6. [DOI: 10.7860/JCDR/2015/10459.5466] [PMID: 25738085]

27. Kumar DK, Rathan N, Mohan S, Begum M, Prasad B, Prasad ER. Exercise prescription to prevent musculoskeletal disorders in dentists. J Clin Diagn Res. 2014; 8(7): ZE13-16. [DOI: 10.7860/ JCDR/2014/7549.4620] [PMID: 25177661]

Received: 26.02.2018 • Accepted: 18.05.2018 


\title{
Muskuloskeletna oboljenja kod stomatologa na stomatološkoj klinici u Skoplju
}

\author{
Vasilka Rendžova, Sonja Apostolska, Marina Eftimoska, Biljana Džipunova, Vesna Filipovska \\ Univerzitet „Sv. Ćirilo i Metodije“, Stomatološki fakultet, Skoplje, Makedonija
}

\begin{abstract}
KRATAK SADRŽAJ
Uvod Muskuloskeletni poremećaji su jedno od najčešćih oboljenja koja nastaju kao posledica rada kod većine zdravstvenih radnika, a naročito stomatologa. Cilj ovog rada je bio da se proveri prisustvo muskuloskeletnih poremećaja kod stomatologa zaposlenih na Univerzitetskoj stomatološkoj klinici u Skoplju i napravi korelacija sa faktorima rizika.

Materijal i metode Ispitivanje je sprovedeno kod 78 stomatoloških praktičara u dobi između 20 i 60 godina, koji su zaposleni na univerzitetskoj stomatološkoj klinici. Pitanja su uključivala podatke o fizičkom i psihosocijalnom opterećenju, opštem zdravlju i pojavi mišićno-skeletnih bolesti u poslednjih 12 meseci, hroničnim bolestima, učestalosti i dužini odmora, radnim navikama i traženju medicinske pomoći.

Rezultati Bol u leđima, vratu i ramena (84,6\% / 85,9\%) bio je najčešći problem kod većine ispitanika, dok je smanjen opseg kretanja primećen kod znatno manjeg broja ispitanika, uglavnom između 40i 60 godina starosti. Dugotrajna statička pozicija se smatra jednim od glavnih uzroka muskuloskeletnih poremećaja (MSD) (82,05\%), dok je 73,08\% ispitanika navelo više od dva razloga kao uzrok. Zaključak Procenat prevalencije MSD kod zubara u sektoru javnog zdravstva je visok. Potrebno je poduzeti obimnija istraživanja kako bi se pokrila veća grupa stomatologa iz privatnog i javnog sektora, da bi se dobila potpuna analiza prevalencije profesionalnih poremećaja u našoj zemlji.

Ključne reči: zubari; ergonomija; mišićno-skeletni poremećaji
\end{abstract}

\section{UVOD}

Prema američkom odeljenju za bezbednost i zdravstvenoj administraciji, mišićno-skeletni poremećaji nastaju kao rezultat neravnoteže između fizičkog napora na radnom mestu i fizičkog kapaciteta radnika [1].

Profesionalne bolesti, pored fizičkih, psiholoških i socijalnih bolesti, imaju ekonomske i sigurnosne posledice kada počnu direktno da utiču na radne kapacitete, do sve češćeg odsustva sa posla i prevremenog penzionisanja [2]. Neke profesionalne opasnosti u stomatologiji vezane su za izloženost hemijskim supstancama, zračenju, opasnim biološkim materijalima i neadekvatan položaj tela tokom rada. Na osnovu podataka dobijenih iz baze podataka o profesionalnoj informativnoj mreži i baze podataka Ministarstva rada SAD, stomatologija je rangirana kao profesija sa visokim rizikom po zdravlje radnika [3].

Muskuloskeletni poremećaji su jedno od najčešćih oboljenja koje nastaje kao posledica rada kod većine zdravstvenih radnika, a naročito stomatologa. Postoji više faktora koji dovode do muskuloskeletnih poremećaja kod stomatologa [4]: neprekidno kretanje, nedovoljno osvetljenja, nepravilno držanje tela tokom rada, psihološki stres, genetika, fizički uslovi, starost i težina $[5,6]$.

Ergonomija je nauka koja se bavi dizajnom opreme za rad i propisima koji osiguravaju maksimalnu efikasnost i sigurnost tokom rada. Takođe ispituje odnos između radnika, opreme i radnog okruženja. Primena ergonomskih uslova i principa na radnom mestu je važan element u prevenciji muskuloskeletnih poremećaja i poboljšanju produktivnosti i efikasnosti stomatologa na duži period [7].

Imajući ovo u vidu, cilj ovog rada je bio da proveri prisustvo muskuloskeletnih poremećaja kod stomatologa zaposlenih na Univerzitetskoj stomatološkoj klinici u Skoplju i napravi korelaciju sa faktorima rizika vezanim za rad.

\section{METODOLOGIJA}

Ispitivanje je sprovedeno kod 78 stomatologa praktičara u dobi između 20 i 60 godina, zaposlenih u javnoj zdravstvenoj ustanovi Stomatološki klinički centar. Ispitanici su dobili standardni upitnik za Nordisk koji se sastoji od dva dela [8]. Prvi deo sadrži pitanja koja se tiču pola i starosti ispitanika, godina radnog iskustva, prosečnog radnog vremena (dnevno i nedeljno), broja i dužine njihovih pauza tokom rada i položaja tela tokom rada.

Drugi deo (Standardni Nordijski upitnik) sastojao se od pitanja koja se odnose na mišićno-skeletne poremećaje, prisustvo genetske predispozicije, učestalost upotrebe lekova protiv bolova i pitanja vezanih za dijagnostikovana MSD i zahteve za medicinskom pomoći.

Pored standardnog upitnika, dat je i još jedan upitnik koji je sadržao pitanja o frekvenciji i dužini pauze, o položaju tela tokom rada, nošenju ortopedske obuće, navikama za vežbanje, istezanju mišića tokom radnog dana i korišćenju alternativnih metoda zdravstvene zaštite kao što su centri za masažu, odnosno poznavanju ergonomskih principa rada i njihove primene. Dobijeni rezultati su analizirani deskriptivnom statističkom analizom.

\section{REZULTATI}

Istraživanje je sprovedeno na 79,59\% (79/98) od ukupnog broja stomatologa na Univerzitetskoj stomatološkoj klinici u Skoplju. Razlozi zbog kojih ostali zaposleni nisu bili deo istraživanja bili su odsustvo zbog bolesti, nedostatka vremena i drugih subjektivnih razloga. Uzorak se sastojao od $87,18 \%$ specijalista (iz oblasti oralne hirurgije, protetike, ortodoncije, dečje stomatologije, parodontologije i endodoncije) i 12,82\% opštih stomatologa. Većina učesnika je imala završene postdiplomske studije (magistarske ili doktorske studije). 
Položaj među našim učesnicima nije bio ravnopravan. Ženskog pola je bilo 73,08\% ispitanika, sa prosečnim radnim iskustvom od 16,9 godina. Prosečno radno iskustvo muških učesnika bilo je 17,24 godine. Osim toga, broj efektivnog radnog vremena kod 82,05\% ispitanika je iznosio 30 sati nedeljno, dok je 17,95\% (uglavnom muškarci) radilo efektivno i 40 sati nedeljno.

Tabela 1 prikazuje razloge vezane za rad koji uzrokuju poremećaje mišićno-skeletnog sistema ili neugodnost. U opisu posla, $82,05 \%$ je izjavilo da provode dugi period u istoj poziciji, $52,56 \%$ je prijavilo da je njihov rad povezan sa istezanjem, kod 62,82\% ispitanika to su ponavljajući pokreti. Da su vibracije mašinskih instrumenata sastavni deo njihovog rada izjavilo je $66,67 \%$ ispitanika, dok se 73,08\% ispitanika u opisu rada odlučilo za dve ili više ponuđenih karakteristika.

Još jedan deo našeg istraživanja fokusirao se na bol i druge žalbe vezane za mišićno-skeletni sistem (Tabela 2) - 66 ispitanika (84,61\%) prijavilo je bol u donjem delu leđa, od čega 33,33\% u zadnjih 12 meseci. Bol u donjem delu leđa je primećen kod $60,26 \%$ ispitanika, od kojih se u $19,23 \%$ bol javio u poslednjih 12 meseci. Smanjen raspon pokreta imalo je $14,10 \%$ ispitanika (starosne grupe od 40 do 60 godina sa prosečnom dužinom radnog iskustva od 22,5 godina). Nijedan od ispitanika iz starosne grupe od 20 do 40 godina nije prijavio bolove u leđima. Većina ispitanika $(85,9 \%)$ obe starosne grupe prijavilA je bol u ramenima i vratu. Štaviše, $28(35,9 \%)$ ispitanika je prijavilo bol u prstima ruke, dok je 14\% ispitanika doživelo gubitak osetljivosti tokom rada. Svi su imali višestruke muskuloskeletne tegobe. Što se tiče upotrebe lekova protiv bolova, $47,44 \%$ ispitanika ih vrlo često koristi, dok ih 33,33\% ispitanika koristi povremeno. Međutim, uprkos visokoj prevalenciji pritužbi među ispitanicima, samo $37,18 \%$ je tražilo stručnu pomoć i imalo dijagnostikovano MSD.

Rezultati su dalje pokazali da je $51,28 \%$ ispitanika upoznato sa ergonomskim principima rada, dok je ostalih $43,59 \%$ samo delimično upoznato. Delimična primena ergonomskih principa primećena je kod 55,13\% ispitanika, a samo 14 ispitanika $(17,95 \%)$ potpuno ih primenjuje tokom rada. Još jedan od zaključaka je bio da većina ispitanika $(67,97 \%)$ radi kombinovano (sedeći i stojeći), a samo 6,41\% ispitanika (uglavnom iz grupe od 20 do 40 godina) radi u sedećem položaju (Tabela 3 ).

Gotovo svi ispitanici smatraju da vežbanje, masaža, fizikalna terapija i druge alternativne metode utiču na mišićno-skeletni sistem i smanjuju pojavu mišićno-skeletnih poremećaja, ali samo $40(51,28 \%)$ ponekad ide na fizikalnu terapiju, a 41,03\% povremeno na masaže. Vežbanje i vežbe istezanja mišića, kao neke od najvažnijih faktora za očuvanje zdravlja mišićno-skeletnog sistema kod stomatologa, često praktikuje samo 26 (33,33\%) ispitanika, dok $48 \%$ vežba samo povremeno (Tabela 3 ).

\section{DISKUSIJA}

Termin MSD odnosi se na povrede koje utiču na meka tkiva kao što su mišići, tetive, ligamenti, zglobovi, hrskavica i nervni sistem. To su kumulativni poremećaji uzrokovani traumom, ponavljajućim pokretima, stresom ili kao sindrom profesionalnog preopterećenja. Generalno se razvijaju postepeno tokom nekoliko nedelja, meseci i godina i obično su bolni i mogu onesposobiti pacijenta [9].
Nekoliko studija je ispitivalo odnos između pojave MSD i vrste profesije. Stomatolozi pripadaju ranjivoj grupi koja je stalno izložena pofesionalnim oboljenjima zbog statičke pozicije, kontinuirano duži period. Drugi faktori koji doprinose prisustvu MSD su nedostatak malih pauza, stalno ponavljajući pokreti ruku i zglobova i istezanje tokom rada $[10,11]$. Još jedan važan faktor koji utiče na pojavu mišićno-skeletnih poremećaja je radno okruženje. Custodio smatra da se pozicije koje preporučuju ISO i FDI, kako za pacijenta, tako i za zubara (tj. ležeća pozicija pacijenta i postavljanje zubara na poziciju „devet sati“) retko primenjuju zbog ograničenih radnih prostora [12]. U svojoj studiji, Burke, Main i Freeman su došli do zaključka da je otprilike jedna trećina stomatologa prisiljena da se ranije penzioniše zbog poteškoća vezanih za rad [13]. Brojne stomatološke studije kažu da su u proseku dva od tri stomatologa doživela muskuloskeletni bol $[14,15]$. Najčešće prijavljeni poremećaji kod zubara su poremećaji kičme, ramena i zgloba, koji mogu dovesti do bolova u leđima, bolu u vratu, brahijalnom bolu, tendinitisa na ramenima, sindroma karpalnog tunela itd. $[16,17,18]$.

Sartorio, Vercelli, Ferriero i sar. ukazuju na veće prisustvo MSD (54-93\%) među stomatološkim osobljem u Italiji i značajno veći rizik od izloženosti kod starijih i ženskih stomatologa [19]. Ova studija je dalje pokazala da su najviše pogođeni kičma, ramena, lakat i ruke.

Naše istraživanje je obavljeno kako bi se videla prevalencija mišićno-skeletnih poremećaja kod zubara u najvećoj javnoj zdravstvenoj ustanovi u zemlji. Ispitivanje je obuhvatilo 78 stomatologa starosti od 20 do 60 godina, oba pola i iz različitih specijalnosti, a većina ih je sa postdiplomskim studijama (magistarske ili doktorske studije).

Bol u leđima, vratu i ramenima najčešći je problem među većinom ispitanika, dok je smanjen opseg kretanja primećen kod značajno manjeg broja ispitanika, uglavnom između 40 i 60 godina života. Zanimljiv je podatak da su svi ispitanici prijavili više od jednog mišićnoskeletnog poremećaja.

Pored toga, bol u ruci je zastupljen sa značajno nižim procentom u odnosu na bol u leđima, vratu i ramenima, koji je povezan i zavisi od vrste specijalnosti. Naše ispitivanje je obuhvatilo ispitanike iz različitih područja specijalnosti, kod kojih je zajednicčko pozicioniranje vrata, ramena i kičme tokom rada. Istezanje i vibracije tokom rada su karakteristični za određene specijalnosti kojima je zajedničko korišćenje ruku i prstiju, što je razlog za nizak procenat žalbi povezanih sa poremećajima ruku i prstiju.

Rezultati našeg istraživanja poklapaju se sa rezultatima koje je iznelo nekoliko autora. Legg i Smith ispitali su 285 australijskih stomatologa, od kojih je 90\% praktikovalo opštu stomatologiju, a većina njihovih problema je povezana sa vratom, ramenima i leđima. Oko 37,5\% stomatologa tražilo je medicinsku pomoć, dok je $25 \%$ dostiglo tačku invalidnosti, a $9 \%$ je zatražilo produženo odsustvo iz svoje prakse [20]. Alekopoulos i saradnici su zaključili da su problemi sa rukama / zglobovima (46\% / 60\%) od najvećeg značaja za profesionalne mišićno-skeletne poremećaje, a ergonomske i obrazovne intervencije mogu imati značajnu ulogu u njihovoj prevenciji [21].

Nekoliko autora ističe da položaj stomatološke stolice treba prilagoditi prema visini zubara, zajedno sa izvorima svetlosti, kako bi se sprečila pojava MSD [22].

Nadalje, rezultati pokazuju visok procenat bolova u donjem delu leđa, koji se mogu odnositi na uslove rada, odnosno veće 
prisustvo ispitanika sa dugogodišnjim radnim iskustvom ili nemogućnost primene ergonomskih principa rada (neispravno radno mesto, loše osvetljenje, nesposobnost rada u sedištu i dr.).

Dugotrajna statička pozicija se smatra jednim od glavnih uzroka MSD i trebalo bi da bude fokus procene rizika od strane profesionalnih doktora kako bi se olakšao razvoj efikasnih preventivnih strategija $[23,24]$. Ovi nalazi su u skladu sa podacima dobijenim iz našeg istraživanja, u kojem je 82,05\% navelo produženi statički položaj kao uzrok poremećaja, a 73,08\% ispitanika navelo je još dva razloga.

Nedavno je nekoliko istraživanja ukazalo da i drugi faktori, kao što su gojaznost i fizička neaktivnost, utiču na razvoj hroničnog MSD kod stomatologa. Štaviše, zbog iscrpljenosti i zamora, uzrokovanih velikim opterećenjem i dugim radnim vremenom, zubari izbegavaju fizičke vežbe i aktivnosti $[25,26]$.

Objavljena literatura ističe fizičku aktivnost (pilates, aerobik) kao važnu preventivnu ergonomsku meru. Ove vežbe poboljšavaju protok kiseonika u tkivima, čime povećavaju efikasnost. Vežbe istezanja su efikasna mera za opuštanje i smanjenje napetosti mišića uzrokovanih nepravilnim držanjem [27]. Poznato je da produženi statički položaj zahteva kontrakciju 50\% telesnih mišića, što ukazuje na potrebu za istezanjem.

Iako svi ispitanici iz našeg istraživanja smatraju da je redovno vežbanje od izuzetnog značaja za mišićno-skeletno zdravlje, samo jedna trećina ispitanika redovno vežba, a $48 \%$ vežba samo povremeno. Procenat koji ukazuje na korišćenje drugih alternativnih metoda kao što su masaža ili spa centri je još niži. Pored visokog procenta mišićno-skeletnih bolesti među ispitanicima, samo $37,18 \%$ je zatražilo stručnu pomoć, a svega $47 \%$ uzimaju lekove za smanjivanje bolova, što može biti rezultat nehata ispitanika ili neodgovoran pristup po ovom pitanju.

Ova studija pokazuje stanje zdravlja doktora stomatologije u javnom sektoru. Ostaje da se istraže položaji lekara iz privatnih stomatoloških ustanova, gde borba za pacijente i njihovo očuvanje nameće složeniji raspored rada, manje pauza i slobodnog vremena, kao i ređe odsustvo s posla.

\section{ZAKLJUČAK}

U zaključku se može reći da je procenat zastupljenosti MSD kod zubara u javnom sektoru zdravstva visok. Potrebno je preduzeti opsežnija istraživanja kako bi se pokrila veća grupa stomatologa iz privatnog i javnog sektora i dobila potpuna slika o postojanju profesionalnih oboljenja u našoj zemlji. Shodno tome, trebalo bi preduzeti odgovarajuće mere informisanja, edukovanja i podizanja svesti kod zubara o činjenici da stomatologija nosi visok rizik od profesionalnih oboljenja i povreda, a samim tim i potencijalno ranog završetka karijere, i načinima na koje da se to spreči. 